Article

\title{
Regional Variability of Agriculturally-Derived Nitrate-Nitrogen in Shallow Groundwater in China, 2004-2014
}

\author{
Jing Li ${ }^{1,2}$, Zhibin He ${ }^{1, *}$, Jun Du ${ }^{1}$, Liwen Zhao ${ }^{1}$, Longfei Chen ${ }^{1}$, Xi Zhu ${ }^{1,2}$, Pengfei Lin ${ }^{1,2}$, \\ Shu Fang 1,2, Minmin Zhao ${ }^{1,2}$ and Quanyan Tian ${ }^{1,2}$ \\ 1 Linze Inland River Basin Research Station, Chinese Ecosystem Research Network, Key Laboratory of \\ Eco-hydrology of Inland River Basin, Northwest Institute of Eco-Environment and Resources, \\ Chinese Academy of Sciences, Lanzhou 730000, China; lijing@lzb.ac.cn (J.L.); dujun159@126.com (J.D.); \\ zhaoliwen@lzb.ac.cn (L.Z.); chenlongfei_mail@163.com (L.C.); zhuxi101@1zb.ac.cn (X.Z.); \\ linpengfei@lzb.ac.cn (P.L.); fangs@lzb.ac.cn (S.F.); zhaomm@lzb.ac.cn (M.Z.); tianquany@126.com (Q.T.) \\ 2 University of Chinese Academy of Sciences, Beijing 100049, China \\ * Correspondence: hzbmail@lzb.ac.cn
}

Received: 10 March 2018; Accepted: 25 April 2018; Published: 2 May 2018

\begin{abstract}
Increasing diffuse nitrate loading of groundwater has long been a major environmental and health concern in China, but little is known about the spatial and temporal variability of nitrate concentrations in groundwater at regional scales. The aim of this study was to assess the spatial distribution and variation of nitrate-nitrogen $\left(\mathrm{NO}_{3}{ }^{-}-\mathrm{N}\right)$ concentrations in groundwater. We used groundwater quality monitoring data and soil physical characteristics from 21 agro-ecosystems in China for years 2004 to 2014. The results indicated that $\mathrm{NO}_{3}{ }^{-}-\mathrm{N}$ concentrations were highly variable in shallow groundwater across the landscape. Over the study period, most of the $\mathrm{NO}_{3}{ }^{-}-\mathrm{N}$ concentrations were below the World Health Organization permissible limit for drinking water $(<10 \mathrm{mg} \mathrm{N} \cdot \mathrm{L}) \cdot \mathrm{NO}_{3}{ }^{-}-\mathrm{N}$ concentrations in groundwater neither significantly increased nor decreased in most agro-ecosystems, but fluctuated with seasons. In addition, groundwater $\mathrm{NO}_{3}{ }^{-}-\mathrm{N}$ under purple soil $\left(6.81 \mathrm{mg} \cdot \mathrm{L}^{-1}\right)$ and Aeolian sandy soil $\left(6.02 \mathrm{mg} \cdot \mathrm{L}^{-1}\right)$ were significantly higher $(p<0.05)$ than that under other soil types, and it was medium-high $\left(4.49 \mathrm{mg} \cdot \mathrm{L}^{-1}\right)$ under aquic cinnamon soil. Elevated nitrate concentrations occurred mainly in oasis agricultural areas of northwestern China, where farmlands with coarse-textured soils use flood irrigation. Therefore, arid and semi-arid areas are expected to sustain high $\mathrm{NO}_{3}{ }^{-}-\mathrm{N}$ concentrations in groundwater. Mitigation strategies can prevent this problem, and include control of $\mathrm{N}$ fertilizer input, balanced fertilization, proper rotation system, adoption of improved irrigation methods, and establishment of environmental policies.
\end{abstract}

Keywords: shallow groundwater; agro-ecosystems; $\mathrm{NO}_{3}{ }^{-}-\mathrm{N}$ concentration; China

\section{Introduction}

Anthropogenic activities across the world affect the quality of groundwater, and result in a severe problem for society [1]. Increasing diffuse nitrate $\left(\mathrm{NO}_{3}{ }^{-}\right)$loading of groundwater has emerged as a serious environmental issue, due to its adverse effects on human populations and natural ecosystems [2,3]. The ingestion of nitrate by humans in drinking water was linked to methemoglobinemia in infants, and to stomach cancers in adults [4,5]. Additionally, high nitrate-nitrogen $\left(\mathrm{NO}_{3}{ }^{-}-\mathrm{N}\right)$ concentrations have also led to eutrophication in aquatic systems inducing depletion of dissolved oxygen $\left(\mathrm{O}_{2}\right)$ (hypoxia) due to increased biological activity $[6,7]$. Moreover, nitrate can persist in groundwater for decades, and it can also take decades for nitrate leached from the soil to discharge into freshwaters. Once groundwater is contaminated, it is 
expensive, and, in many cases, virtually impossible to clean up [8]. Because of those concerns, the U.S. Environmental Protection Agency (U.S. EPA) established a maximum contaminant level (MCL) of $10 \mathrm{mg} \cdot \mathrm{L}^{-1} \mathrm{NO}_{3}{ }^{-} \mathrm{N}$ in drinking water [9]. In China, the permissible $\mathrm{NO}_{3}{ }^{-}-\mathrm{N}$ concentration in groundwater is $20 \mathrm{mg} \cdot \mathrm{L}^{-1}$ [10]. In recent years, groundwater nitrate contamination has been found in the United States, UK, The Netherlands, The Czech Republic, Denmark, Lebanon, China, Japan, India, Israel, New Zealand, and many other countries. In some regions of Denmark and The Netherlands, nitrate concentrations have been increasing by 0.2 to $1.3 \mathrm{mg} \cdot \mathrm{L}^{-1}$ per year [5]. Research on groundwater nitrate in China has been carried out in agricultural regions since the 1990s. Studies have indicated that the Circum-Bohai-Sea Region, including the provinces of Beijing, Hebei, Henan, Shandong, Liaoning, Tianjin, and Shanxi, had high $\mathrm{NO}_{3}{ }^{-}-\mathrm{N}$ concentrations in groundwater, with an average value of $11.9 \mathrm{mg} \cdot \mathrm{L}^{-1}$; about $34.1 \%$ of the groundwater exceeded the WHO (World Health Organization) limit of $10 \mathrm{mg} \cdot \mathrm{L}^{-1}$ for drinking water [11]. In addition, many studies also suggested that $32.4 \%$ of wells in the middle of the Heihe River irrigation areas exceeded the limit of $10 \mathrm{mg} \mathrm{NO}_{3}{ }^{-}-\mathrm{N} \mathrm{L}^{-1}$ [12].

Generally, anthropogenic nitrogen inputs, primarily via the application of synthetic fertilizers and the cultivation of leguminous crops, were the main sources of nitrate contamination in soil and groundwater in many agricultural areas of the world [13]. In several cases, groundwater under agricultural ecosystems was at a greater risk of contamination by nitrate than that under other types of ecosystems [14]. Empirical correlations relating increased use of inorganic fertilizers, their application rates, and nitrate leaching suggest that inorganic fertilizers contribute nitrate to the soil directly. Moreover, field studies also have confirmed that high $\mathrm{N}$ fertilizer rates increased the risks of nitrate $\left(\mathrm{NO}_{3}{ }^{-}\right)$accumulation in the soil profile and of groundwater nitrate pollution [15,16]. Unfortunately, rates of $\mathrm{N}$ inputs have now reached the levels of diminishing returns for crop yield in China, and China has one of the lowest nationally-averaged NUE (nitrogen use efficiency) values in the world [17]. For example, regions where $\mathrm{N}$-fertilizer application rates were above $500 \mathrm{~kg} \mathrm{~N}^{-1}$ and $\mathrm{N}$ use efficiency was less than $40 \%$ were at a high risk of nitrate pollution of shallow groundwater [18]. Additionally, nitrate concentration in groundwater had a significant spatial variability, which may be mainly controlled by land use type, soil texture, thickness of the vadose zone, timing of fertilizer application, and regional climate [19]. Finally, groundwater nitrate pollution may be the consequence of long-term nitrogen accumulation rather than current practices. In brief, the possible mechanisms that affect nitrate pollution in groundwater likely include multiple factors.

For several decades, nitrate contamination in surface waters and groundwater in China has received considerable attention, and many studies of nitrate pollution of groundwater have been conducted in intensive farming regions. However, little is known about the spatial and temporal variation of nitrate concentrations over wide geographical areas and in different soil types. The aims of this study were to assess the spatial and temporal characteristics of groundwater nitrate on a national scale; to identify and document the long-term trends of nitrate concentrations in groundwater; and to analyze the variability of nitrate especially due to key decision variables such as soil type distribution. The assessment is carried out using monitoring data of the China Ecosystem Research Network (CERN) from 2004 to 2014. This assessment is intended to increase the understanding of the space-time variability in nitrate concentrations in groundwater in agro-ecosystems of China, and to provide recommendations related to future groundwater environmental management.

\section{Materials and Methods}

\subsection{Monitoring Sites}

The mission of CERN is to promote ecosystem conservation and improvement, and monitor changes in the natural environment in China. CERN consists of 31 research stations, including 13 in agricultural ecosystems, 9 in forest ecosystems, 6 in desert ecosystems, 2 in grasslands, and 1 in a wetland ecosystem. All the stations are engaged in monitoring work, research, experiment and demonstration. Water quality monitoring work of CERN had begun in 1998, and consisted 
mainly of long-term monitoring of the quality of liquid surface water, stationary water, groundwater, and precipitation at each station. We selected 21 of the CERN monitoring sites and obtained data for years 2004 to 2014 to evaluate the distribution of groundwater nitrate. Background information, such as mean annual air temperature, mean annual precipitation, $\mathrm{N}$ application rates, crop rotation, and soil type was recorded for each sampling event at each monitoring well. The ecosystems represented by the 21 stations in this study were agricultural and desert, distributed across a range of climatic zones (Figure 1). These agro-ecosystems included (1) northeast agricultural area (HLA, SYA), (2) north oasis agricultural area and pastoral area (CLD, EDS, LZD, NMD, SPD, FKD), (3) north China agricultural area (AKA, ASA, CWA, FQA, YCA, LCA), (4) Tibetan Plateau agricultural and pastoral area (LSA), (5) south agricultural area (YGA, TYA, CSA, YTA, QYA, HJA). The altitude of the selected agro- and desert ecosystems ranged from $1.3 \mathrm{~m}$ (CSA) to $3688 \mathrm{~m}$ (LSA). Mean annual air temperature (MAAT) across the stations ranged from $1.5^{\circ} \mathrm{C}$ at HLA (northeast) to $19.9^{\circ} \mathrm{C}$ at HJA (south), and the mean annual precipitation (MAP) ranged from $33 \mathrm{~mm}$ at CLD (north) to $1785 \mathrm{~mm}$ at YTA (south) (Table 1). In addition, data on soil physical properties used in this study were also obtained from CERN.

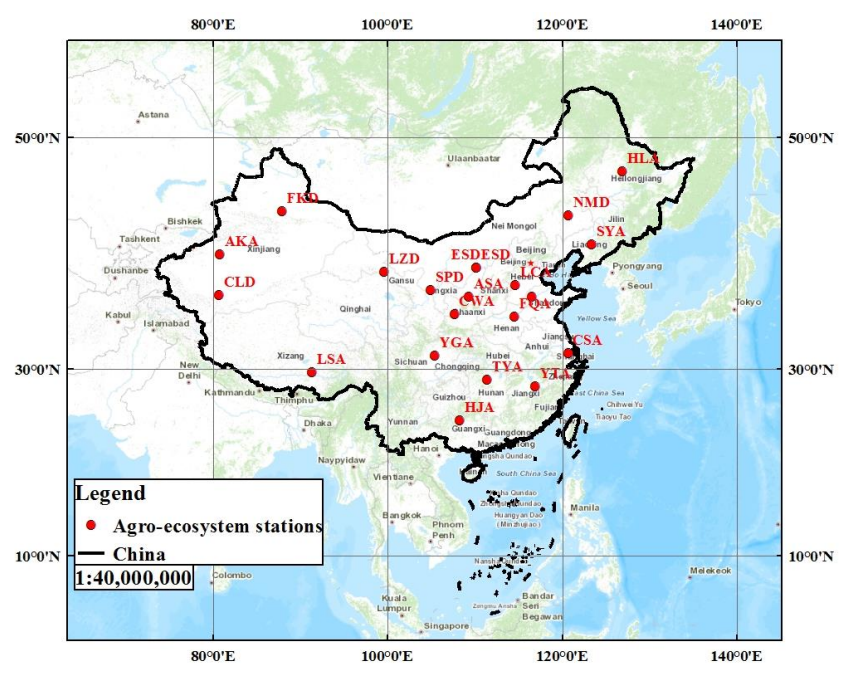

Figure 1. Distribution of groundwater wells used in this study. Groundwater wells are part of ecological stations in the Chinese Ecosystem Research Network (CERN). Letters in red font represent station names.

Table 1. Geographical location and environmental conditions of the 21 typical agricultural ecosystems in this study. MAAT: mean annual air temperature; MAP: mean annual precipitation.

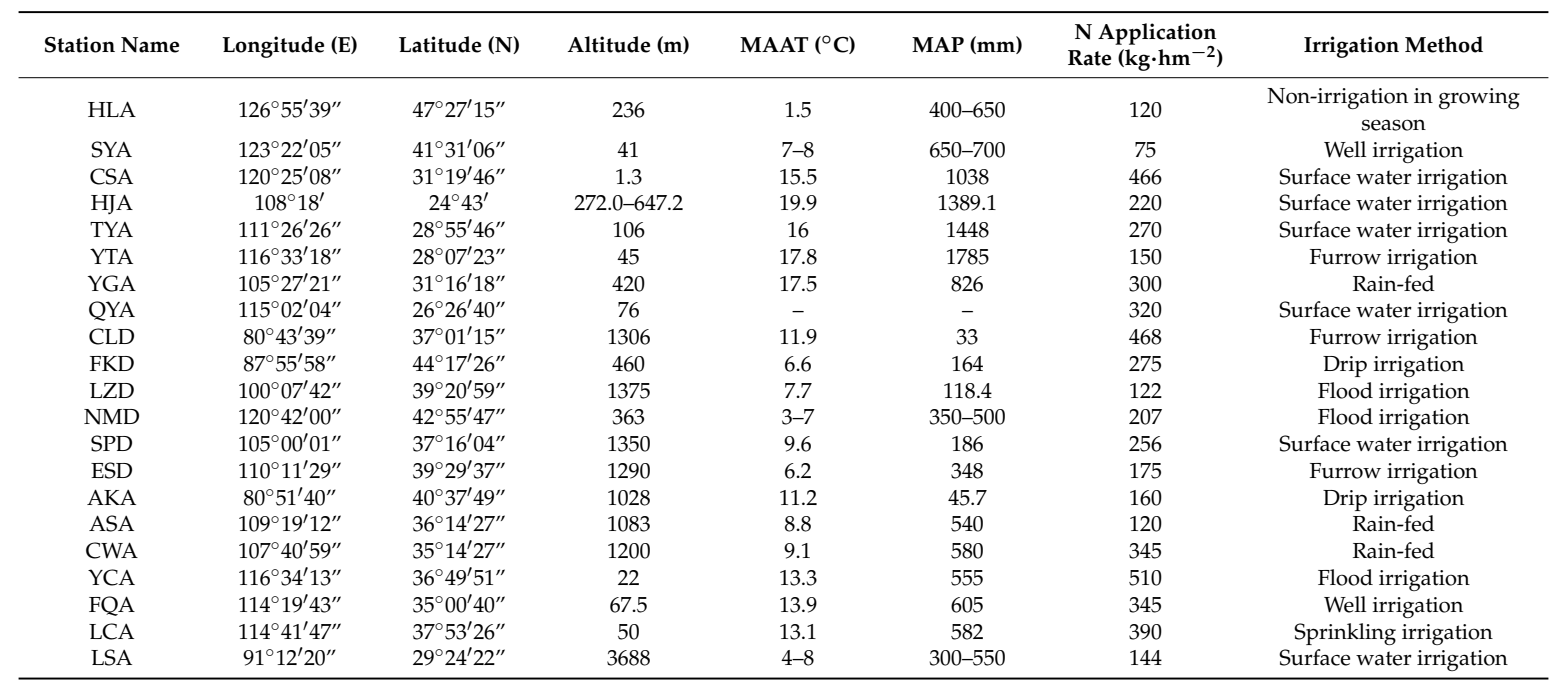




\subsection{Monitoring Methods}

Groundwater water sampling and analysis were strictly based on the Water Monitoring Protocol of the Chinese Ecosystem Research Network [20]. In order to ensure data quality, a three-tier (i.e., field stations, water sub-center, and synthesis center) data quality control was used for the CERN monitoring data. The field stations conduct groundwater water sampling and analysis according to the laboratory quality control standards. Water sub-center is responsible for the quality data. The synthesis center mainly assesses data quality of the entire CERN [21]. $\mathrm{NO}_{3}{ }^{-}-\mathrm{N}$ values that were larger than the total $\mathrm{N}$ concentration for any sample, were eliminated from analysis database. For this study, 39 groundwater monitoring wells were selected for long-term monitoring, including 16 wells under farmland to evaluate variability in groundwater nitrate under conditions of long-term fertilization and crop planting. About 1660 groundwater samples were collected and analyzed by field station personnel. Most datasets spanned years 2004 to 2014 (FKD, NMD, SPD, CWA, LSA, HLA, SYA, YCA, FQA, LCA, CSA, TYA, YGA, QYA), some datasets spanned years 2005 to 2014 (CLD, LZD, ESD, ASA), one spanned years 2007 to 2014 (HJA), one spanned years 2006 to 2014 (YTA), and one spanned years 2008 to 2014 (AKA). At most stations, groundwater was sampled 4 times per year, but at YCA, FQA, CSA, YTA, sampling was conducted monthly. Nitrate was measured by ion chromatography, also known as phenoldisulfonic acid spectrophotometry, using Bran-Lubbe AA3, (Germany). Non-parametric methods were used to test for outliers in the datasets. The Kruskal-Wallis test was used to test the differences among different soil types.

Soil samples were analyzed at the Chinese Science Academy's laboratory, following standard protocols and methods [20]. Soil sampling protocol is detailed in Zhang et al. [22]. Soil data were used to determine soil textures and soil water characteristics of farmland in agro-ecosystems of CERN. Soil sampling was conducted every five years to depths of 40 to $400 \mathrm{~cm}$ of total soil depth to bedrock. Nitrate concentration of soil profiles was measured before and after planting, and after fertilization. Because soil data in agro-ecosystems were not fully analyzed, complete datasets from 15 stations (HLA, SYA, CSA, TYA, YTA, YGA, QYA, SPD, LDZ, ASA, CWA, FQA, YCA, LCA, LSA) only were used to evaluate the effects of soil texture on nitrate concentrations in soil and groundwater (Table 2).

Table 2. Physical characteristics of soil, and soil nitrate-N in agro-ecosystems of CERN.

\begin{tabular}{|c|c|c|c|c|c|c|}
\hline \multirow{2}{*}{ Sites } & \multirow{2}{*}{ Soil Type (USDA) } & \multirow{2}{*}{ Land Use Type } & $\begin{array}{c}\text { Soil Saturation } \\
\text { Moisture Content }\end{array}$ & $\begin{array}{l}\text { Soil Field } \\
\text { Capacity }\end{array}$ & $\begin{array}{c}\text { Sandy Particle } \\
\text { Content }(0-100 \mathrm{~cm})\end{array}$ & $\begin{array}{l}\text { Soil Nitrate-N Content } \\
(20 \mathrm{~cm} \text { Depth) }\end{array}$ \\
\hline & & & \multicolumn{3}{|c|}{$\%$} & $(\mathrm{mg} \cdot \mathrm{kg}-1)$ \\
\hline HLA & Black soil & Maize-soybean & 41.3 & 35.3 & 27.0 & - \\
\hline CSA & Paddy soil & Paddy-wheat & 33.9 & 29.8 & 9.4 & 8.7 \\
\hline TYA & Red soil & Paddy & 29.0 & 26.6 & 17.0 & 2.4 \\
\hline YTA & Red soil & Peanut & 33.8 & 26.5 & 21.6 & 2.4 \\
\hline LZD & Aeolian sandy soil & Wheat-maize & 42.3 & 21.7 & 86.6 & 3.2 \\
\hline ASA & Loess soil & Maize-soybean & 45.2 & 18.8 & 28.6 & 5.3 \\
\hline CWA & Malan loess & Maize-wheat & 38.7 & 21.0 & 10.7 & 7.1 \\
\hline FQA & Fluvo-aquic soil & Maize-wheat & 65.8 & 38.8 & 31.5 & 29.0 \\
\hline YCA & Fluvo-aquic soil & Maize-wheat & 51.4 & 36.4 & 15.3 & 47.0 \\
\hline LCA & Aquic cinnamon soil & Maize-wheat & 51.0 & 36.7 & 52.7 & 28.6 \\
\hline
\end{tabular}

\subsection{Statistical Methods}

All statistical analyses were performed by IBM SPSS Statistics ver. 19.0 (Chicago, IL, USA). Analysis of variance (ANOVA) was used to assess significant differences in nitrate $\mathrm{N}$ concentrations between different soil types. Simple linear fitting was used to fit the trends of nitrate concentration in groundwater in LZD and YGA stations. 


\section{Results}

\subsection{Nitrate Concentrations in Groundwater under Different Agro-Ecosystems}

Concentrations of $\mathrm{NO}_{3}{ }^{-}-\mathrm{N}$ in most of the groundwater samples were below the permissible limits for drinking water $\left(<10 \mathrm{mg} \mathrm{N} \cdot \mathrm{L}^{-1}\right)$, except for that at ASA $\left(33.26 \pm 22.47 \mathrm{mg} \mathrm{N} \cdot \mathrm{L}^{-1}\right)($ Table 3). This was despite nitrate $\mathrm{N}$ fertilization rates in these fields of 75 to $510 \mathrm{~kg} \cdot \mathrm{hm}^{-2}$. The average $\mathrm{NO}_{3}{ }^{-}-\mathrm{N}$ concentration across the 39 wells beneath the 21 field stations was $4.26 \mathrm{mg} \cdot \mathrm{L}^{-1}$. The average groundwater level ranged from 0.54 to $84.5 \mathrm{~m}$, and mean $\mathrm{NO}_{3}{ }^{-}-\mathrm{N}$ concentration ranged from 0.23 to $33.26 \mathrm{mg} \cdot \mathrm{L}^{-1}$. In that, mean $\mathrm{NO}_{3}{ }^{-}-\mathrm{N}$ concentrations in groundwater at most of the monitored stations in the Northeast and South agricultural areas were below $2 \mathrm{mg} \cdot \mathrm{L}^{-1}$ (HLA, SYA, CSA, HJA, TYA, YTA, QYA). Mean $\mathrm{NO}_{3}{ }^{-}-\mathrm{N}$ concentration in groundwater at the Northwest oasis agricultural and pastoral area ranged from 0.97 to $8.42 \mathrm{mg} \cdot \mathrm{L}^{-1}$. Mean groundwater $\mathrm{NO}_{3}{ }^{-}-\mathrm{N}$ concentration at the Northwest oasis (CLD, FKD, LZD, NMD, SPD, ESD) was $3.84 \mathrm{mg} \cdot \mathrm{L}^{-1}$, higher than that in the Northeast (HJA, SYA) (mean value was $0.26 \mathrm{mg} \cdot \mathrm{L}^{-1}$ ) and South agricultural ecosystems (CSA, HJA, TYA, YTA, YGA, QYA) (mean value was $2.0 \mathrm{mg} \cdot \mathrm{L}^{-1}$ ).

Table 3. Nitrate-N concentrations and background information on the monitoring wells in agro-ecosystems of CERN.

\begin{tabular}{|c|c|c|c|c|c|c|}
\hline & \multirow{2}{*}{$\begin{array}{l}\text { Station } \\
\text { Name }\end{array}$} & \multirow{2}{*}{$\begin{array}{l}\text { Number of } \\
\text { Wells }\end{array}$} & \multirow{2}{*}{$\begin{array}{l}\text { Average Groundwater } \\
\text { Level }(\mathrm{m})(\text { Mean } \pm \text { S.E.) }\end{array}$} & \multicolumn{2}{|c|}{$\mathrm{NO}_{3}{ }^{-}-\mathrm{N}\left(\mathrm{mg} \cdot \mathrm{L}^{-1}\right)$} & \multirow{2}{*}{$\begin{array}{l}\quad>10 \mathrm{mg} \cdot \mathrm{L}^{-1} \\
\text { Frequency of Nitrate-N (\%) }\end{array}$} \\
\hline & & & & Max & Mean \pm S.E. & \\
\hline \multirow{2}{*}{$\begin{array}{c}\text { Northeast } \\
\text { agricultural area }\end{array}$} & HLA & 1 & $20.4 \pm 2.0$ & 0.45 & $0.29 \pm 0.05$ & 0 \\
\hline & SYA & 2 & $7.8 \pm 3.7$ & 1.07 & $0.23 \pm 0.18$ & 0 \\
\hline \multirow{6}{*}{$\begin{array}{c}\text { South } \\
\text { agricultural area }\end{array}$} & CSA & 1 & $0.54 \pm 0.4$ & 7.95 & $1.33 \pm 1.06$ & 0 \\
\hline & HJA & 1 & $3.53 \pm 2.12$ & 0.9 & $0.90 \pm 0.09$ & 0 \\
\hline & TYA & 1 & $2.62 \pm 0.63$ & 4.23 & $0.81 \pm 0.70$ & 0 \\
\hline & YTA & 2 & $3.85 \pm 1.25$ & 2.5 & $1.11 \pm 0.79$ & 0 \\
\hline & YGA & 3 & $2.28 \pm 1.37$ & 26.08 & $6.80 \pm 4.09$ & 16.8 \\
\hline & QYA & 2 & $2.57 \pm 1.33$ & 12.09 & $1.06 \pm 1.38$ & 15 \\
\hline \multirow{6}{*}{$\begin{array}{l}\text { Northwest oasis } \\
\text { agricultural and } \\
\text { pastoral area }\end{array}$} & CLD & 3 & $14.5 \pm 0.2$ & 9.62 & $4.04 \pm 1.26$ & 0 \\
\hline & FKD & 2 & $3.4 \pm 0.4$ & 3.52 & $1.87 \pm 0.63$ & 0 \\
\hline & LZD & 2 & $4.3 \pm 0.6$ & 21.5 & $8.42 \pm 1.85$ & 40.9 \\
\hline & NMD & 3 & $7.6 \pm 0.2$ & 6.35 & $0.97 \pm 0.75$ & 0 \\
\hline & SPD & 1 & $15.2 \pm 0.4$ & 6.37 & $4.54 \pm 1.60$ & 0 \\
\hline & ESD & 1 & $9.98 \pm 2.15$ & 10.52 & $3.17 \pm 2.07$ & 48.8 \\
\hline \multirow{2}{*}{$\begin{array}{l}\text { North China } \\
\text { agricultural }\end{array}$} & FQA & 4 & $4.2 \pm 0.43$ & 3.9 & $0.79 \pm 0.63$ & 0 \\
\hline & LCA & 1 & $37.3 \pm 3.7$ & 8.49 & $4.49 \pm 1.40$ & 0 \\
\hline $\begin{array}{l}\text { Tibet plateau } \\
\text { agricultural }\end{array}$ & LSA & 3 & $2.8 \pm 1.6$ & 8.13 & $6.05 \pm 0.07$ & 0 \\
\hline
\end{tabular}

\subsection{Temporal Variation of Nitrate Concentrations in Groundwater under Different Agro-Ecosystems}

The results of groundwater monitoring indicated that the variability in $\mathrm{NO}_{3}{ }^{-}-\mathrm{N}$ concentration presented a significant seasonal trend in most agro-ecosystems (Figure 2). $\mathrm{NO}_{3}{ }^{-}-\mathrm{N}$ concentrations in SYA and HLA agro-ecosystems were high in May and June, respectively, while those in northwestern (NMD) and North China agro-ecosystems (FQA) were significantly higher in August and September than in any other months. Additionally, maximum groundwater nitrate concentration was observed in June in southern agro-ecosystems, such as YGA.

We also found that nitrate concentration in groundwater did not increase under intensive cultivation and under the present rate of heavy fertilization in most typical agro-ecosystems of CERN except for LZD and YGA (Figure 2). However, at LZD, nitrate concentration in groundwater tended to increase over time $\left(\mathrm{R}^{2}=0.717, p<0.01\right)$. The minimum and maximum values of $\mathrm{NO}_{3}{ }^{-}-\mathrm{N}^{-}$ concentrations in groundwater in LZD were 0.72 and $21.49 \mathrm{mg} \cdot \mathrm{L}^{-1}$, respectively, with an average of $8.42 \mathrm{mg} \cdot \mathrm{L}^{-1}$. Further, (1) the annual average $\mathrm{NO}_{3}{ }^{-}-\mathrm{N}$ concentration in 2014 was 7.1 times higher than that in 2004, (2) $\mathrm{NO}_{3}{ }^{-}-\mathrm{N}$ concentrations exceeded the WHO-established limits for drinking water of $10 \mathrm{mg} \mathrm{N} \cdot \mathrm{L}^{-1}$ starting in August 2011. Meanwhile, groundwater nitrate concentration at YGA also had 
an increasing trend from 2004 to $2014\left(\mathrm{R}^{2}=0.290, p<0.01\right)$, and the average $\mathrm{NO}_{3}{ }^{-}-\mathrm{N}$ concentration in the monitoring well beneath this farmland was $9.82 \mathrm{mg} \cdot \mathrm{L}^{-1}$. In fact, about $16.8 \%$ of 86 monitored samples at the YGA station exceeded the threshold value.
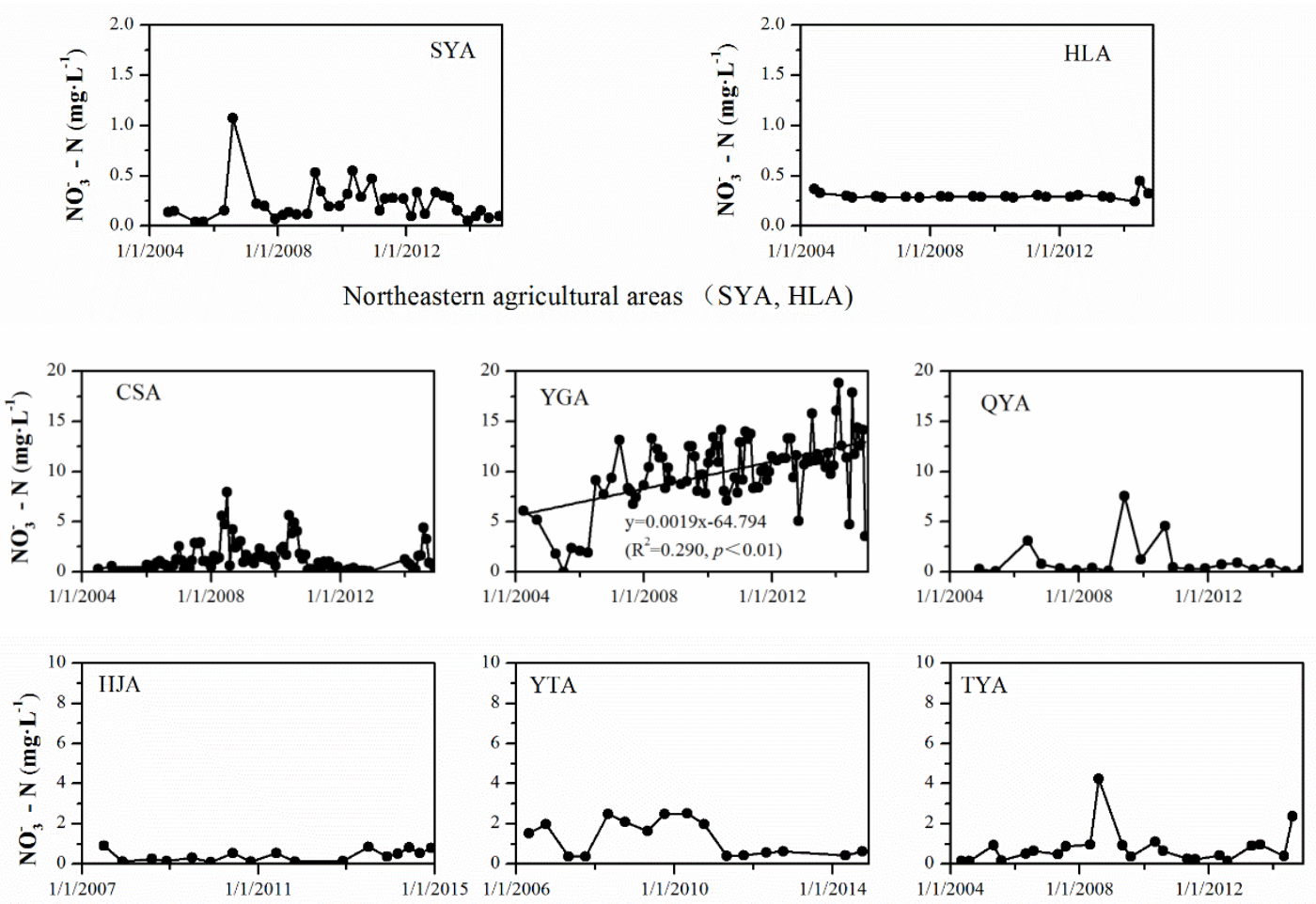

Southern agricultural areas (CSA, YGA, QYA, HJA, YTA, TYA)
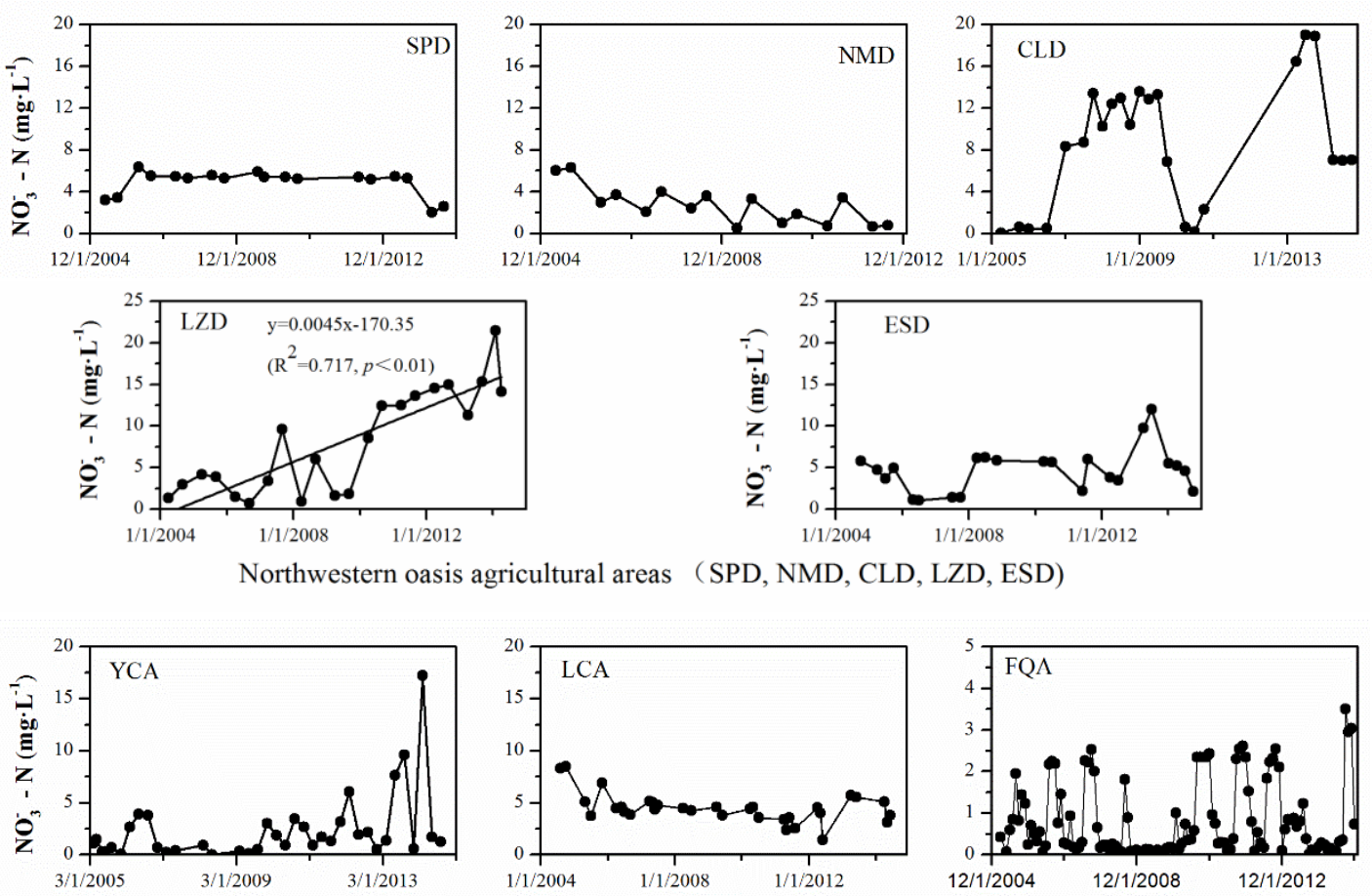

North China agricultural areas (YCA, LCA, FQA)

Figure 2. Temporal variation trends of nitrate-N concentrations in monitoring wells in agro-ecosystems of CERN. 


\subsection{Nitrate Concentration in Groundwater under Different Soil Types}

$\mathrm{NO}_{3}{ }^{-}-\mathrm{N}$ concentrations in groundwater from CERN agro-ecosystems showed significant differences among soil types (Figure 3). Groundwater $\mathrm{NO}_{3}{ }^{-}-\mathrm{N}$ concentration under purple soil $\left(6.81 \mathrm{mg} \cdot \mathrm{L}^{-1}\right)$ and aeolian sandy soil $\left(6.02 \mathrm{mg} \cdot \mathrm{L}^{-1}\right)$ was significantly higher $(p<0.05)$ than that under other soil types. Aquic cinnamon soil in the LCA agro-ecosystem exhibited medium-high groundwater $\mathrm{NO}_{3}{ }^{-}-\mathrm{N}$ concentration $\left(4.49 \mathrm{mg} \cdot \mathrm{L}^{-1}\right)$, while red, fluvo-aquic, meadow, black, aquic brown, and paddy soil had low groundwater $\mathrm{NO}_{3}{ }^{-}-\mathrm{N}$ concentrations with no significant differences. At SPD and LZD stations, sand contents of aeolian sandy soil were highest of all at $72.7 \%$ and $86.6 \%$, respectively, in the 0 - to $100-\mathrm{cm}$ soil, with mean soil $\mathrm{NO}_{3}{ }^{-}-\mathrm{N}$ concentrations of $1.5 \mathrm{mg} \mathrm{kg}^{-1}$ and $3.2 \mathrm{mg} \mathrm{kg}^{-1}(20 \mathrm{~cm}$ depth), respectively (Table 2). Fluvo-aquic soil (FQA, YCA) and aquic cinnamon soil (LCA) had lower sand and higher silt contents than soils at SPD and LZD, with the mean soil $\mathrm{NO}_{3}{ }^{-}-\mathrm{N}$ of $29 \mathrm{mg} \mathrm{kg}^{-1}$. Similarly, paddy soil (CAS) and red soil (TYA, YTA) had low sand and high silt contents, and mean soil $\mathrm{NO}_{3}{ }^{-}-\mathrm{N}$ of $8.7 \mathrm{mg} \mathrm{kg}^{-1}$, and $2.4 \mathrm{mg} \mathrm{kg}^{-1}$, respectively.

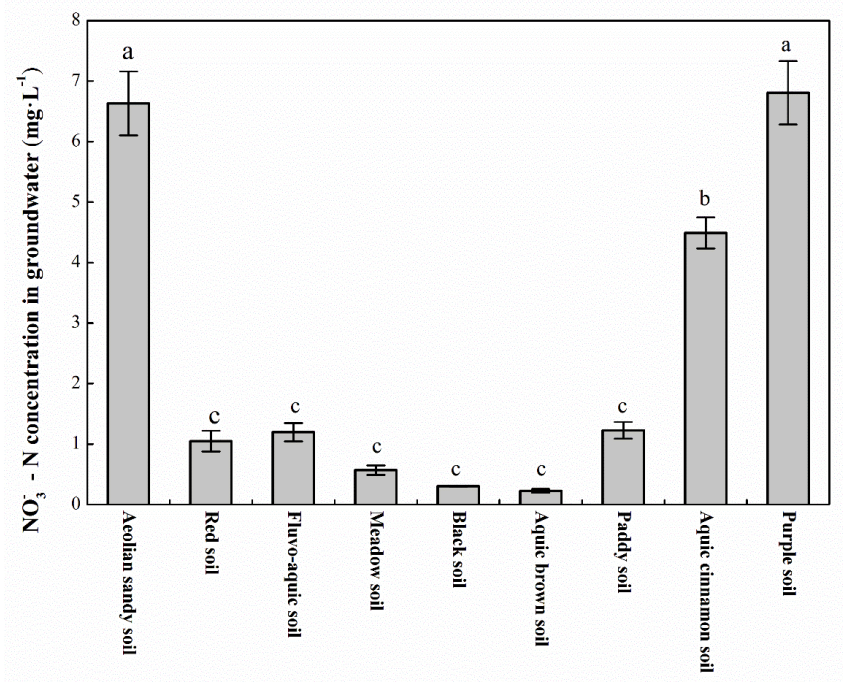

Figure 3. Nitrate-N concentration in groundwater under different soil types in CERN agro-ecosystems. Aeolian sandy soil (CLD, SPD, LZD, ESD), Red soil (YTA, QYA, TYA), Fluvo-aquic soil (YCA, FQA,), Meadow soil (LSA), Black soil (HLA), Aquic brown soil (SYA), Paddy soil (CSA), Aquic cinnamon soil (LCA), Purple soil (YGA). Histograms labeled with different letters indicate significant differences at $p<0.05$.

\section{Discussion}

\subsection{Spatial Variation of Nitrate-N Concentrations in Groundwater}

To date, there is still lack of a comprehensive understanding of the distribution of nitrate in the groundwater in China, due to the limited sampling density or lack of necessary hydraulic data. Long-term investigations of site-specific pollution within an isolated region usually provide more information than extensive random sampling with limited numbers of samples. Therefore, in our study, the spatial and temporal variation patterns of nitrate concentrations in groundwater under agricultural activities were investigated based on nearly a decade of groundwater quality data from 21 agro-ecosystems of CERN in China, which could excluded the interference of individual climate events. Our results indicated that concentrations of $\mathrm{NO}_{3}{ }^{-}-\mathrm{N}$ in groundwater of CERN agro-ecosystems were mostly below the permissible limits for drinking water $\left(<10 \mathrm{mg} \mathrm{N} \cdot \mathrm{L}^{-1}\right)$. During 2004 to 2014 , the average $\mathrm{NO}_{3}{ }^{-}-\mathrm{N}$ concentration for the 39 monitoring wells beneath 21 agro-ecosystems was $4.26 \mathrm{mg} \cdot \mathrm{L}^{-1}$, higher than observed in a study conducted from 2004 to $2010\left(4.1 \pm 0.33 \mathrm{mg} \cdot \mathrm{L}^{-1}\right.$; [22]). This indicated that $\mathrm{NO}_{3}{ }^{-}-\mathrm{N}$ concentration has been increasing at $0.05 \mathrm{mg} \cdot \mathrm{L}^{-1}$ per year (from 2010 to 
2014). Generally, in agricultural ecosystems, agricultural activity is the most significant human factor influencing nitrogen sources and generating nitrate pollution in groundwater. High application rates of $\mathrm{N}$ fertilizer have a significant potential for nitrate leaching $[3,23]$. Research suggests that $8-12 \%$ of the applied fertilizer, applied at $120 \mathrm{~kg} \mathrm{~N} \cdot \mathrm{ha}^{-1} \cdot \mathrm{y}^{-1}$, leaked toward the hydrosphere [24]. In China, $15-30 \%$ of the labeled fertilizer $\mathrm{N}$, applied at $160 \mathrm{~kg} \mathrm{~N} \cdot \mathrm{ha}^{-1} \cdot \mathrm{y}^{-1}$, remained in the soil after harvest [25]. In this study, the rate of $\mathrm{N}$ fertilization varied widely among regions and crops, and elevated $\mathrm{NO}_{3}{ }^{-}-\mathrm{N}$ concentrations were observed in sites with high and with low rates of applied $\mathrm{N}$ fertilizer. For example, in the CLD and LCA agro-ecosystem, the annual average $\mathrm{N}$ fertilizer application rates were 468 and $390 \mathrm{~kg} \mathrm{~N} \cdot \mathrm{ha}^{-1}$, respectively, with the corresponding mean $\mathrm{NO}_{3}{ }^{-}-\mathrm{N}$ concentrations of 4.04 and $4.49 \mathrm{mg} \cdot \mathrm{L}^{-1}$. However, the average $\mathrm{N}$ fertilizer application rates in ASA and LZD were relatively low (120 and $122 \mathrm{~kg} \mathrm{~N} \cdot \mathrm{ha}^{-1}$ ), while the mean $\mathrm{NO}_{3}{ }^{-}-\mathrm{N}$ concentrations (33.26 and $8.42 \mathrm{~kg} \mathrm{~N} \cdot \mathrm{ha}^{-1}$ ) were relatively high.

Additionally, we also found that nitrate concentrations in groundwater in all agro-ecosystems differed significantly with climate. For example, relatively high nitrate concentrations were observed in arid and semi-arid climate of the Northwest oasis agricultural ecosystem (CLD, FKD, LZD, NMD, SPD, ESD), where the mean nitrate concentration of groundwater was higher than that in humid and semi-humid region of the Northeast (HJA, SYA) and in humid region of the South agricultural ecosystems (CSA, HJA, TYA, YTA, YGA, QYA). In southern high-rainfall areas, nitrate leaching is the main cause of groundwater pollution [25], while in arid and semi-arid regions, rainfall is relatively scarce, and continuous recharge of groundwater from precipitation is almost negligible [26,27]. However, occasional heavy rainfall can transport surface $\mathrm{NO}_{3}{ }^{-}$deep into the soil profile, and cause $\mathrm{N}$ loss by surface runoff, especially in the Loess Plateau [28]. For example, ASA agro-ecosystem is a typical hilly loess terrain of the Loess Plateau. Because topography of the loess area is fragmented, and loess soil is very thick with low porosity, rates of nitrification are high $\left(2-5 \mathrm{mg} \mathrm{kg}^{-1} \mathrm{~d}^{-1}\right)$ [28]. Also, in-depth studies revealed that the chemical characteristics of shallow groundwater in the loess area exhibited a significant spatial variability, with high nitrate. Moreover, irrigation was another important influencing factor in elevated nitrate concentration in groundwater, because irrigation water not only promoted the leaching of $\mathrm{N}$ fertilizer into shallow groundwater, but also reduced the potential for ammonia volatilization [29]; ammonia volatilization is a major pathway for reducing nitrate concentrations [30]. In arid and semi-arid agro-ecosystems such as ASA, YCA, LZD, NMD, FKD, CLD, and SPD, crop productivity depends heavily on irrigation, which may make groundwater susceptible to nitrate-N pollution. Our results suggested that high application rates of $\mathrm{N}$ fertilizer combined with flood irrigation may cause nitrate-N pollution in specific regions, but not necessarily act as the sole factor influencing nitrate-N pollution of groundwater. This finding further supports the idea that the hydrographical and geographical conditions were involved in a possible mechanism affecting the spatial characteristics of nitrate diffusion to groundwater on the national scale.

\subsection{Temporal Variation of Nitrate-N Concentrations in Groundwater}

Generally, the dynamic changes and temporal trends of nitrate concentrations were explored using long-term monitoring datasets [22,31,32]. Based on the long-term observation data, we investigated the dynamic of groundwater nitrate- $\mathrm{N}$ concentrations under agricultural activities. The results of our study showed that $\mathrm{NO}_{3}{ }^{-}-\mathrm{N}$ concentrations neither significantly increased nor decreased in the majority of the wells except for those in the LZD and YGA agro-ecosystems. In LZD and YGA stations, we found that $\mathrm{NO}_{3}{ }^{-}-\mathrm{N}$ concentration had an increasing trend from 2004 to 2014; increasing nitrate levels may accumulate over time and pollute groundwater. For instance, the mean $\mathrm{NO}_{3}{ }^{-}-\mathrm{N}$ concentration at the LZD monitoring wells in the Zhangye Oasis was $8.42 \mathrm{mg} \cdot \mathrm{L}^{-1}$. Similarly, Yang et al. [12] observed in the Zhangye Oasis that mean $\mathrm{NO}_{3}{ }^{-}-\mathrm{N}$ concentration in groundwater was $10.66 \mathrm{mg} \cdot \mathrm{L}^{-1}$, and $32.4 \%$ of 71 wells exceeded the WHO-established limits for drinking water $\left(10 \mathrm{mg} \mathrm{N} \cdot \mathrm{L}^{-1}\right)$, confirm that groundwater in long-term oasis agro-ecosystems was seriously contaminated $\mathrm{NO}_{3}{ }^{-}-\mathrm{N}$. At the YGA station in Sichuan Province, $\mathrm{NO}_{3}{ }^{-}-\mathrm{N}$ concentration in $16.8 \%$ of the samples was above $10 \mathrm{mg} \mathrm{N} \cdot \mathrm{L}^{-1}$, 
suggesting that nitrate pollution had occurred in this area due to facilitation of accumulated nitrate movement into subsurface flow by the slopes and purple soil [33]. Moreover, vegetable cultivation was another main contributor to $\mathrm{NO}_{3}{ }^{-}-\mathrm{N}$ content in groundwater, while precipitation and well depth also influenced groundwater $\mathrm{NO}_{3}{ }^{-}-\mathrm{N}$ contents $[22,33,34]$.

Here, temporal trends showed that $\mathrm{NO}_{3}{ }^{-}-\mathrm{N}$ concentrations neither significantly rose nor fell in majority of the wells (Figure 2), but in general, it exhibited a seasonal fluctuation in monitored regions. However, the highest and lowest $\mathrm{NO}_{3}{ }^{-}-\mathrm{N}$ concentrations in different agro-ecosystems were observed in different seasons. Thus, $\mathrm{NO}_{3}{ }^{-}-\mathrm{N}$ peaked in wet season, and dropped to the lowest level in dry season in regions which included irrigation areas in northern China; this was similar to the seasonal concentration patterns reported for two farmlands in northern China [35]. In contrast, high values of nitrate were observed during the rainy season in July and August in some rain-fed farming regions of southern China (CSA, YGA, TYA). It is very likely that the seasonal increase in nitrate concentration occurred due to nitrogen leaching into groundwater with rainfall or irrigation. For most northern agricultural areas, elevated nitrate concentrations in winter were likely associated with winter irrigation. Field experiments with a continuous winter wheat-summer maize double-cropping rotation showed that residual nitrate from summer moved out of the $0-100 \mathrm{~cm}$ soil profile during winter due to winter flood irrigation [36].

\subsection{Nitrate-N Concentrations in Groundwater under Different Soil Types}

In this study, we found that $\mathrm{NO}_{3}{ }^{-}-\mathrm{N}$ concentrations in wells beneath purple and aeolian sandy soils were significantly higher $(p<0.05)$ than those under other soil types, and that aquic cinnamon soil in the LCA agro-ecosystem exhibited medium-high concentration of groundwater $\mathrm{NO}_{3}{ }^{-}-\mathrm{N}$ $\left(4.49 \mathrm{mg} \cdot \mathrm{L}^{-1}\right)$. Purple soil is characterized by a shallow soil layer $(60 \mathrm{~cm})$, and a low- infiltration parent material. Subsurface runoff was the main pathway of nitrate leaching in purple soil in the rainy season [35]. Annual average loss of $\mathrm{NO}_{3}{ }^{-}-\mathrm{N}$ through subsurface flow was $27.29 \mathrm{~kg} \cdot \mathrm{ha}^{-1}$, accounting for $10 \%$ of total $\mathrm{N}$ fertilizer application rate $\left(280 \mathrm{~kg} \cdot \mathrm{hm}{ }^{-2}\right)$ within a year [37]. Therefore, nitrate leaching from hilly crop land in purple soils results in groundwater pollution. In northern China, most soils are calcareous, including aeolian sandy and aquic cinnamon soils (with a $\mathrm{pH}$ of about 8), where $\mathrm{NO}_{3}{ }^{-}$cannot be retained. Research has shown a negative correlation between the retention of $\mathrm{NO}_{3}{ }^{-}-\mathrm{N}$ and sandy contents in soils [38]. Sandy soils usually have higher water permeability rates than do loam soils [39], promoting leaching of $\mathrm{N}$ fertilizer into shallow groundwater in arid and semiarid oasis agricultural ecosystems. This corresponds with the results of Su et al. [40], who found that newly-cultivated sandy farmlands were prone to nitrate leaching, and at high-risk for groundwater nitrate pollution.

Here, we also found that there was no significant difference in $\mathrm{NO}_{3}{ }^{-}-\mathrm{N}$ concentrations in wells in the red, fluvo-aquic, meadow, black, aquci brown and paddy soils. In southern humid and semi-humid areas, $\mathrm{NO}_{3}{ }^{-}-\mathrm{N}$ concentration in groundwater in paddy ecosystems (CSA, TYA, QYA) was usually lower than in other land use types because of finer-grained sediments and favorable drainage. Lowest amounts of $\mathrm{NO}_{3}{ }^{-}-\mathrm{N}$ in the 0 - to $400 \mathrm{~cm}$ soil profile were observed near Beijing City in paddy fields compared with commercial vegetables, orchards, winter wheat-summer maize rotation, and spring corn fields [35].

\subsection{Mitigation Measures}

$\mathrm{NO}_{3}{ }^{-}-\mathrm{N}$ pollution of groundwater jeopardizes the sustainability of groundwater resources and agricultural productivity in some regions. However, implementation of preventive management and legislation can help to reduce $\mathrm{NO}_{3}{ }^{-}-\mathrm{N}$ accumulation and leaching from soil.

Typically, reducing total $\mathrm{N}$ input is the most effective and direct way to reduce $\mathrm{NO}_{3}{ }^{-}-\mathrm{N}$ leaching [28]. Because soil fertility varies significantly from location to location, it is necessary to optimize $\mathrm{N}$ fertilizer applications, and to incorporate a fertilizer formula based on soil fertility status and plant $\mathrm{N}$ demand. Further, research has shown that the application of phosphorus in combination 
with $\mathrm{N}$ can reduce leaching of $\mathrm{NO}_{3}{ }^{-}-\mathrm{N}$ in the soil profile [41,42], and that this effect can be enhanced by the use of manure [40,43].

Additionally, extreme rainfall events or excessive irrigation may promote nitrate leaching into deep soil. Therefore, reducing or eliminating summer fallow and planting catch crops during winter played an important role in decreasing residual soil $\mathrm{N}$ and minimizing $\mathrm{NO}_{3}{ }^{-}-\mathrm{N}$ leaching $[44,45]$. The adoption of advanced irrigation methods, such as drip irrigation, soil-less culture, and greenhouses can reduce the quantity of nitrate available in the soil, thus reducing $\mathrm{N}$ leaching losses to groundwater and preventing groundwater pollution [46].

Finally, selecting proper rotation scheduling, reducing the frequency of summer fallow, and using alternative crops may be effective in preventing nitrate leaching after harvest. Raising awareness among farmers about the dangers of groundwater nitrate pollution, and formulating agricultural environmental policies and legislation need to be incorporated as critical components of efforts to address issues of water quality.

\section{Conclusions}

In China, $\mathrm{NO}_{3}{ }^{-}-\mathrm{N}$ concentration in groundwater in agro-ecosystems varied significantly with climate and topography. Mean groundwater $\mathrm{NO}_{3}{ }^{-}-\mathrm{N}$ concentration of 21 agro-ecosystems was $4.26 \mathrm{mg} \cdot \mathrm{L}^{-1}$, and increased $0.4 \%$ after 2010 . In general, $\mathrm{NO}_{3}{ }^{-}-\mathrm{N}$ concentrations in northern and northwestern agro-ecosystems were relatively higher than those in northeast and southern agro-ecosystems. Temporal trends showed that $\mathrm{NO}_{3}{ }^{-}-\mathrm{N}$ concentrations neither significantly increased nor decreased in majority of the monitored wells except for LZD and YGA, but exhibited a seasonal fluctuation in monitored regions. $\mathrm{NO}_{3}{ }^{-}-\mathrm{N}$ concentrations at the LZD and YGA stations were slowly increasing from 2004 to 2014, suggesting that nitrate may accumulate over time and pollute groundwater. Moreover, groundwater $\mathrm{NO}_{3}{ }^{-}-\mathrm{N}$ concentrations under purple soil $\left(6.81 \mathrm{mg} \cdot \mathrm{L}^{-1}\right)$ and aeolian sandy soil $\left(6.02 \mathrm{mg} \cdot \mathrm{L}^{-1}\right)$ were significantly higher $(p<0.05)$ than those under other soil types. Aquic cinnamon soil in LCA agro-ecosystem exhibited medium-high groundwater nitrate-N concentration $\left(4.49 \mathrm{mg} \cdot \mathrm{L}^{-1}\right)$, while red, fluvo-aquic, meadow, black, aquic brown and paddy soils had low groundwater $\mathrm{NO}_{3}{ }^{-}-\mathrm{N}$ concentrations with no significant difference.

The problem of elevated nitrate concentration of groundwater was observed in specific areas. For example, the observation wells of agro-ecosystems in arid and semi-arid regions had elevated nitrate concentration, especially at LZD and ASA, where groundwater nitrate pollution is ongoing. Therefore, groundwater in arid, semi-arid, and loess plateau areas would be more vulnerable to contamination from nitrate. Authors should discuss the results and how they can be interpreted in perspective of previous studies and of the working hypotheses. The findings and their implications should be discussed in the broadest context possible. Future research directions may also be highlighted.

Because $\mathrm{NO}_{3}{ }^{-}-\mathrm{N}$ pollution of groundwater can affect the sustainability of groundwater resources and agricultural productivity in some regions, it is necessary to increase the number of monitored groundwater wells and the frequency of monitoring work on a national scale. Further, we recommend implementing some mitigation strategies to alleviate $\mathrm{NO}_{3}{ }^{-}-\mathrm{N}$ pollution of groundwater, such as control of $\mathrm{N}$ fertilizer input, balanced fertilization, proper rotation system, adoption of improved irrigation methods, and establishment of environmental policies. In addition, to pay attention to the serious issues of water quality, we recommend raising awareness among administrators, scientists and farmers.

Author Contributions: The authors contributed equally in research design, data collection and manuscript development.

Acknowledgments: This research was supported by the national key research and development program of China (No. 2017YFC0504306), the Major Program of National Natural Science Foundation of China (No. 41630861), the National Natural Science Foundation of China (No. 41501044) and the CAS “Light of West China" Program. 
We gratefully acknowledge the team of Chinese Ecosystem Research Network, who designed the monitoring networks and collected and analyzed the samples used in this study.

Conflicts of Interest: The authors declare no conflict of interest.

\section{References}

1. Bárdossy, A. Copula-based geostatistical models for groundwater quality parameters. Water Resour. Res. 2006, 42, 11416. [CrossRef]

2. Velthof, G.L.; Lesschen, J.P.; Webb, J.; Pietrzak, S.; Miatkowski, Z.; Pinto, M.; Kros, J.; Oenema, O. The impact of the Nitrates Directive on nitrogen emissions from agriculture in the EU-27 during 2000-2008. Sci. Total Environ. 2014, 468-469, 1225-1233. [CrossRef] [PubMed]

3. Mencio, A.; Mas-Pla, J.; Otero, N.; Regas, O.; Boy-Roura, M.; Puig, R.; Bach, J.; Domenech, C.; Zamorano, M.; Brusi, D.; et al. Nitrate pollution of groundwater; all right..., but nothing else? Sci. Total Environ. 2016, 539, 241-251. [CrossRef] [PubMed]

4. Gulis, G.; Czompolyova, M.; Cerhan, J.R. An ecologic study of nitrate in municipal drinking water and cancer incidence in Trnava District, Slovakia. Environ. Res. 2002, 88, 182-187. [CrossRef] [PubMed]

5. Fazal, A.; Imaizumi, M.; Ishida, S.; Kawachi, T.; Tsuchihara, T.; Takenuchi, J.; Badiul Alam, A.H.M. Review on Groundwater Nitrate Contamination: Causes, Effects and Remedies: A Guideline for Efficient Management Strategies. J. Rainwater Catchment Syst. 2003, 8, 15-33. [CrossRef]

6. Ju, X.T.; Xing, G.X.; Chen, X.P.; Zhang, S.L.; Zhang, L.J.; Liu, X.J.; Cui, Z.L.; Yin, P.; Christie, P.; Zhu, Z.L. Reducing environmental risk by improving $\mathrm{N}$ management in intensive Chinese agricultural systems. Proc. Natl. Acad. Sci. USA 2009, 106, 3041-3046. [CrossRef] [PubMed]

7. Bailey, R.T.; Gates, T.K.; Romero, E.C. Assessing the effectiveness of land and water management practices on nonpoint source nitrate levels in an alluvial stream-aquifer system. J. Contam. Hydrol. 2015, 179, 2-15. [CrossRef] [PubMed]

8. National Research Council. Ground Water Vulnerability Assessment: Contamination Potential under Conditions of Uncertainty. Committee on Techniques for Assessing Ground Water Vulnerability. In Water Science and Technology Board, Commission on Geosciences, Environment, and Resources; National Academy Press: Washington, DC, USA, 1993.

9. U.S. Environmental Protection Agency Office of Water. Drinking Water Regulations and Health Advisories; US Environmental Protection Agency, Office of Water: Washington, DC, USA, 1996.

10. Department of Geology and Mineral Resources. China National Standard: Quality Standard for Ground Water; GB/T 14848-93; Department of Geology and Mineral Resources: Beijing, China, 1994.

11. Ma, H.; Li, X.X.; Hu, C.S. Status of Nitrate Nitrogen Contamination of Groundwater in China. Chin. J. Soil Sci. 2012, 43, 1532-1536. (In Chinese)

12. Yang, R.; Liu, W.J. Nitrate contamination of groundwater in an agroecosystem in Zhangye Oasis, Northwest China. Environ. Earth Sci. 2009, 61, 123-129. [CrossRef]

13. Sebilo, M.; Mayer, B.; Nicolardot, B.; Pinay, G.; Mariotti, A. Long-term fate of nitrate fertilizer in agricultural soils. Proc. Natl. Acad. Sci. USA 2013, 110, 18185-18189. [CrossRef] [PubMed]

14. Almasri, M.N.; Kaluarachchi, J.J. Assessment and management of long-term nitrate pollution of ground water in agriculture-dominated watersheds. J. Hydrol. 2004, 295, 225-245. [CrossRef]

15. Aulakh, M.S.; Malhi, S.S. Interactions of Nitrogen with Other Nutrients and Water: Effect on Crop Yield and Quality, Nutrient Use Efficiency, Carbon Sequestration, and Environmental Pollution. In Advances in Agronomy; Academic Press: Cambridge, MA, USA, 2005; pp. 341-409.

16. Wakida, F.T.; Lerner, D.N. Non-agricultural sources of groundwater nitrate: A review and case study. Water Res. 2005, 39, 3-16. [CrossRef] [PubMed]

17. Zhang, X.; Davidson, E.A.; Mauzerall, D.L.; Searchinger, T.D.; Dumas, P.; Shen, Y. Managing nitrogen for sustainable development. Nature 2015, 528, 51-59. [CrossRef] [PubMed]

18. Zhang, W.L.; Tian, Z.X.; Zhang, N.; Li, X.Q. Nitrate pollution of groundwater in northern China. Agric. Ecosyst. Environ. 1996, 59, 223-231. [CrossRef]

19. Mclay, C.D.; Dragten, R.; Sparling, G.; Selvarajah, N. Predicting groundwater nitrate concentrations in a region of mixed agricultural land use: A comparison of three approaches. Environ. Pollut. 2001, 115, 191-204. [CrossRef] 
20. Yuan, G.F.; Tang, D.Y.; Sun, X.M. Water Monitoring Protocol of Chinese Ecosystem Research Network; China Environmental Science Press: Beijing, China, 2007.

21. Li, S.; Yu, G.; Yu, X.; He, H.; Guo, X. A brief introduction to Chinese Ecosystem Research Network (CERN). J. Resour. Ecol. 2015, 6, 192-196.

22. Zhang, X.Y.; Xu, Z.W.; Sun, X.M.; Dong, W.Y.; Ballantine, D. Nitrate in shallow groundwater in typical agricultural and forest ecosystems in China, 2004-2010. J. Environ. Sci. 2013, 25, 1007-1014. [CrossRef]

23. Kim, H.; Park, S. Hydrogeochemical Characteristics of Groundwater Highly Polluted with Nitrate in an Agricultural Area of Hongseong, Korea. Water 2016, 8, 345. [CrossRef]

24. Castellano, M.J.; David, M.B. Long-term fate of nitrate fertilizer in agricultural soils is not necessarily related to nitrate leaching from agricultural soils. Proc. Natl. Acad. Sci. USA 2014, 111, E766. [CrossRef] [PubMed]

25. Ju, X.T.; Liu, X.J.; Zhang, F.S.; Roelcke, M. Nitrogen Fertilization, Soil Nitrate Accumulation, and Policy Recommendations in Several Agricultural Regions of China. Ambio 2004, 33, 300-305. [CrossRef] [PubMed]

26. Qi, S.Z.; Luo, F. Water environmental degradation of the Heihe River Basin in arid northwestern China. Environ. Monit. Assess. 2005, 108, 205-215. [CrossRef] [PubMed]

27. Qin, D.J.; Qian, Y.P.; Han, L.F.; Wang, Z.M.; Li, C.; Zhao, Z.F. Assessing impact of irrigation water on groundwater recharge and quality in arid environment using CFCs, tritium and stable isotopes, in the Zhangye Basin, Northwest China. J. Hydrol. 2011, 405, 194-208. [CrossRef]

28. Fan, J.; Hao, M.D.; Malhi, S.S. Accumulation of nitrate $\mathrm{N}$ in the soil profile and its implications for the environment under dryland agriculture in northern China: A review. Can. J. Soil Sci. 2010, 90, 423-429. [CrossRef]

29. Di, H.J.; Cameron, K.C. Nitrate leaching in temperate agro-ecosystems, sources, factors and mitigating strategies. Nutr. Cycl. Agro-Ecosyst. 2002, 46, 237-256. [CrossRef]

30. Zhang, S.L.; Cai, G.X.; Wang, X.Z.; Xu, Y.H.; Zhu, Z.L.; Ferney, J.R. Losses of urea-nitrogen applied to maize on a calcareous flubo-aquic soil in North China Plain. Pedosphere 1992, 2, 171-178.

31. Harter, T.; Davis, H.; Mathews, M.C.; Meyer, R.D. Shallow groundwater quality on dairy farms with irrigated forage crops. J. Contam. Hydrol. 2002, 55, 287-315. [CrossRef]

32. Williams, M. Groundwater Level and Nitrate Concentration Trends on Mountain Home Air Force Base, Southwestern Idaho. Open-File Rep. 2014. [CrossRef]

33. Xu, Z.W.; Zhang, X.Y.; Sun, X.M.; Yuan, G.F.; Wang, S.Z.; Liu, W.H. Assessment of shallow groundwater nitrate concentrations in typical terrestrial ecosystems of Chinese Ecosystem Research Network (CERN) during 2004-2009. Environ. Scie. 2011, 32, 2827-2833.

34. Wang, T.; Zhu, B.; Cao, M.R.; Xu, T.P.; Kuang, F.H. Nitrate pollution of groundwater in a typical small watershed in the Central Sichuan Hilly Region. J. Ecol. Rural Environ. 2006, 22, 84-87.

35. Liu, H.B.; Li, Z.H.; Zhang, Y.G. Characteristics of Nitrate Distribution and Accumulation in Soil Profiles under Main Agro-land Use Types in Beijing. Sci. Agric. Sin. 2004, 37, 692-698.

36. Ju, X.T.; Liu, X.J.; Zhang, F.S. Accumulation and movement of $\mathrm{NO}_{3}{ }^{-}-\mathrm{N}$ in soil profile in winter wheat-summer maize rotation system. Acta Pedol. Sin. 2003, 40, 538-546.

37. Zhu, B.; Wang, T.; Kuang, F.; Xu, T.; Tang, J.; Wu, Y. Characteristics of nitrate leaching from hilly cropland of purple soil. Acta Sci. Circumst. 2008, 28, 525-533.

38. Gaines, T.P.; Gaines, S.T. Soil texture effect on nitrate leaching in soil percolates. Commun. Soil Sci. Plant Anal. 1994, 25, 2561-2570. [CrossRef]

39. Jamieson, R.C.; Gordon, R.J.; Sharples, K.E.; Stratton, G.W.; Madani, A. Movement and persistence of fecal bacteria in agricultural soils and subsurface drainage water: A review. Can. Biosyst. Eng. 2002, 44, 1-1.

40. Su, Y.Z.; Yang, R. Background concentrations of elements in surface soils and their changes as affected by agriculture use in the desert-oasis ecotone in the middle of Heihe River Basin, North-west China. J. Geochem. Explor. 2008, 98, 57-64. [CrossRef]

41. Yuan, X.M.; Tong, Y.A.; Yang, X.Y.; Li, X.L.; Zhang, F.S. Effect of phosphate application on soil nitrate nitrogen accumulation. Plant Nutr. Fertil. Sci. 2000, 6, 397-403.

42. Yang, Z.P.; Mei, X.; Gao, F.; Li, Y.; Guo, J. Effect of Different Nitrogen Fertilizer Types and Application Measures on Temporal and Spatial Variation of Soil Nitrate-Nitrogen at Cucumber Field. J. Environ. Prot. 2013, 4, 129-135. [CrossRef]

43. Yang, R.; Su, Y.Z.; Wang, T.; Yang, Q. Effect of chemical and organic fertilization on soil carbon and nitrogen accumulation in a newly cultivated farmland. J. Integr. Agric. 2016, 15, 658-666. [CrossRef] 
44. Campbell, C.A.; Dejong, R.; Zentner, R.P. Effect of cropping, summer fallow and fertilizer nitrogen on nitrate-nitrogen lost by leaching on a Brown Chernozemic soil. Can. J. Soil Sci. 1984, 64, 61-74. [CrossRef]

45. Vos, J.; van der Putten, P.E.L.; Hussein, M.H.; van Dam, A.M.; Leffelaar, P.A. Field observations on nitrogen catch crops. II. Root length and root length distribution in relation to species and nitrogen supply. Plant Soil 1998, 210, 149-155. [CrossRef]

46. Malki, M.; Bouchaou, L.; Hirich, A.; Ait, B.Y.; Choukrallah, R. Impact of agricultural practices on groundwater quality in intensive irrigated area of Chtouka-Massa, Morocco. Sci. Total Environ. 2017, 574, 760-770. [CrossRef] [PubMed]

(C) 2018 by the authors. Licensee MDPI, Basel, Switzerland. This article is an open access article distributed under the terms and conditions of the Creative Commons Attribution (CC BY) license (http://creativecommons.org/licenses/by/4.0/). 